Terbit online pada laman web jurnal : http://teknosi.fti.unand.ac.id/

\title{
Sistem Informasi Penjualan Berbasis Kinerja pada Proyek Apartemen Mega City Bekasi
}

\author{
Dyani Ayu Aisyah ${ }^{a}$ Kursehi Falgenti ${ }^{b}$ \\ ${ }^{a, b}$ Universitas Indraprasta PGRI, Jl. Raya Tengah No 80 Kel. Gedong Kec Pasar Rebo, Jakarta Timur 13760, Indonesia
}

\begin{tabular}{|c|}
\hline INFORMASI ARTIKEL \\
\hline $\begin{array}{l}\text { Sejarah Artikel: } \\
\text { Diterima Redaksi: } 23 \text { September } 2017 \\
\text { Revisi Akhir: } 27 \text { Desember } 2017 \\
\text { Diterbitkan Online: } 31 \text { Desember } 2017\end{array}$ \\
\hline KATA KUNCI \\
\hline Sistem informasi Penjualan, Pemasaran, Kinerja Pemasaran \\
\hline KORESPONDENSI \\
\hline Telepon: +62 081315177738 \\
\hline E-mail:kursehi_falgenti@unindra.ac.id \\
\hline
\end{tabular}

\section{PENDAHULUAN}

Penggunaan Teknologi Informasi pada kegiatan pemasaran diperlukan untuk mendukung perusahaan berkolaborasi, mengintegrasikan para agen pemasaran agar mampu berinovasi dalam lingkungan bisnis, selain itu untuk meningkatkan adaptasi produk baru terhadap permintaan pasar [1]. Bagi personil pemasaran pemanfaatan Teknologi Informasi dapat meningkatkan layanan kepada pelanggan, kemamapuan beradaptasi dengan penjual dan meningkatkan kinerja penjulan [2]

Adopsi teknologi oleh sales eksekutif memungkinkan mereka bekerja lebih efektif dan efisien. Teknologi membantu sales eksekutif mempercepat penjualan, sehingga mengurangi waktu yang diperlukan untuk menyelesaikan siklus penjualan dan membuatnya lebih berhasil dalam menargetkan calon pembeli yang tepat dan mengubahnya menjadi pelanggan.

Pesatnya perkembangan teknologi infomasi dan ketatnya persaingan bisnis saat ini, mendorong para pemimpin dan pemilik perusahaan memanfaatkan teknologi informasi untuk mendukung tenaga pemasaran. Dalam rangka merealisasikan ketepatan pendekatan penjualan perlu adanya pengolahan data yang

https://doi.org/10.25077/ TEKNOSI.v3i3.2017.343-352

\section{A B $\quad \mathbf{S}$ T $\mathbf{R}$ A $\mathbf{C}$ T}

Mega City Apartment Bekasi is an integrated residence providing shopping and office space developed by PT. Development of Mega Utama. In marketing department Sales data is still manually processed using speadsheet application. There is no centralized data processing with information system support. The purpose of this research is to build a performance-based sales information system at PT. Mega Utama Devepment. The method used in the development of this information system is SDLC. The SDLC model used in the development of this information system is the "Classic Life Cycle" or waterfall model. performance-based sales information system is very helpful marketing personnel in the frontline on the sale of apartment units. They work faster with integrated data support. Sales of apartment units is more effective because interaction with potential customers is supported by an interactive information system. while in the back office this information system serves for marketing managers as a control of the sales force. Marketing Manager can directly know the performance of salespeople based on performance reports on this information system.

terintegrasi dimulai dari proses pendataan barang/jasa yang ingin dijual dan dipasarkan, pendataan konsumen hingga pendataan barang/jasa yang berhasil terjual. Oleh karena itu peningkatan kualitas sumber daya manusia dan pengembangan sistem informasi dengan pemanfaatan teknologi tepat guna dapat mendukung tercapainya strategi pemasaran perusahaan secara optimal.

Di bidang properti, pentingnya sistem informasi di bagian penjualan semakin disadari pengembang. Beberapa Penelitian pengembangan sistem informasi penjulan properti pernah dilakukan diantaranya; di PT. Wika Realty dengan membangun sistem informasi pemesanan KPR berbasis web [3] dan sistem pembayaran tunai dan kredit property PT. Sanggraha Properti [4].

PT. Mega Utama Development Sebagai pengembang Apartemen Mega City Bekasi juga menyadari pentingnya dukungan sistem informasi untuk departemen pemasaran. Selama ini proses pencatatan data penjualan masih dilakukan dengan cara manual. Dicatat tangan oleh sales eksekutif sebagai arsip. Pencatatan menggunakan aplikasi spread sheet dan dicetak sebagai laporan kepada Supervisor dan Sales Manager. Cara manual seperti ini membuat siklus penjualan berjalan lambat mengakibatkan rangkaian pekerjaan penjualan tidak efektif. Proses pengarsipan data konsumen, data booking yang masih sederhana dan 
kesadaran akan pencadangan data juga minim mengakibatkan kemungkinan terjadinya kehilangan data akan mengganggu proses penjualan. Selanjutnya penilaian progress penjualan dan kinerja sales eksekutif belum terkontrol dengan baik karena belum adanya laporan kegiatan yang menunjang aktivitas tersebut.

Penelitian ini bertujuan menbangun sistem penjualan unit apartemen berbasis kinerja untuk mengatasi masalah ketidakefektifan dalam siklus penjualan di PT. Mega Utama Development. Sistem informasi penjualan unit apartemen ini lebih efektif karena mengintegintegrasikan proses bisnis di frontline dengan proses bisnis di back end. Di frontline sistem informasi ini menyediakan fungsi untuk mendata calon pembeli, fungsi penawaran unit apartemen, booking dan pembatalan unit apartemen. Sedangkan di back end menyediakan fungsi menampilkan kinerja tenaga pemasaran untuk membantu Manejer Pemasaran mengawasi aggota timnya. Sistem informasi ini dibangun dengan Bahasa pemograman Java Netbeans dan database MySQL. Metode yang digunakan dalam mengembangan sistem informasi penjualan apartemen berbasis kinerja ini adalah Metode System Development Life Cycle (SDLC) dengan model waterfall. Dengan sistem informasi penjualan berbasis kinerja ini akan sangat membantu meningkatkan efektifitas penjualan serta meningkatkan kinerja divisi marketing PT. Mega Utama Development.

\section{TINJAUAN PUSTAKA}

\subsection{Sistem Informasi}

Pengertian sistem secara umum adalah kumpulan elemen-elemen yang saling berkaitan dan menangani pemrosesan masukan atau input sehingga menghasilkan keluaran yang diinginkan[5]. Sistem informasi adalah suatu sistem di dalam suatu organisasi yang mempertemukan kebutuhan pengolahan transaksi harian yang mendukung fungsi operasi organisasi yang bersifat manajerial dengan kegiatan strategi dari suatu organisasi untuk dapat menyediakan laporan-laporan yang diperlukan oleh pihak luar tertentu [6].

Sedangkan Tantra berpendapat sistem informasi adalah kumpulan dari berbagai prosedur di dalam perusahaan untuk menghasilkan informasi yang dibutuhkan [7]. Sistem informasi mengolah data menjadi informasi yang bernilai untuk mendukung manajemen mengambil keputusan. Karena peran strategisnya ini sistem informasi berperan penting dalam tmbuh kembang organisasi dan perusahaan.

\subsection{Penjualan}

Penjualan merupakan konsep yang harus dipraktekkan paling agresif dengan barang yang umumnya pembeli tidak berpikir untuk membeli [8].

Penjualan merupakan suatu usaha bisnis dalam menjualkan produk/jasa untuk mengembangkan strategi pemasaran dalam memperoleh laba dan meningkatkan strategi pemasaran. Pada keseluruhan proses bisnis penjualan merupakan kegiatan yang terpisah dari semua kegiatan perdagangan lainnya. Penjualan merupakan bagian dari pemasaran. Penjualan melibatkan kontak langsung, satu lawan satu dengan calon pelanggan.

344 Diany Ayu Aisyah

\subsection{Kinerja}

[9] menemukan definisi kinerja atau prestasi tersebut dapat dijabarkan menjadai tiga bagian:

A. Adalah "prestasi" yang digunakan dalam konteks suatu kalimat misalnya "mobil yang sangat cepat" ("high performance car").

B. Adalah "pertunjukan" yang biasanya digunakan dalam kalimat "folk dance performance" atau "pertunjukan taritarian rakyat".

C. Adalah "pelaksanaan tugas" misalnya dalam kalimat "in performing his/her duties".

Dalam bahasa Inggris sendiri sebenarnya ada sebuah kata atau istilah lain yang lebih menggambarkan "prestasi", dalam pengertian Indonesia atau sebagaimana digunakan dalam bahasa Indonesia yaitu kata "achievement". Tetapi karena kata itu berasal dari kata "to achieve" yang berarti "mencapai", lebih sering diterjemahkan menjadi "pencapaian" atau "apa yang dicapai". Dalam konteks sistem manajemen kerja, apa yang disebut umpan balik atau feedback diartikan sebagai pemberitahuan oleh orang atasan kepada bawahannya tentang kinerja yang dicapai oleh bawahan tersebut, apakah dianggap baik atau buruk.

Dapat disimpulkan, kinerja merupakan sebuah prestasi berupa umpan balik atau feedback yang didapatkan oleh seseorang termasuk karyawan dalam memaksimalkan usaha. Dalam dunia penjualan kinerja ini didapatkan melalui hasil penjualan dari pelaksanaan tugas menjual terhadap target yang ditentukan dan memaksimalkan mutu pelayanan dalam menjual.

\section{METODOLOGI}

Penelitian ini adalah penelitian kualitatif dengan studi kasus di Proyek Apaertemen Mega City Bekasi yang dikembangkan oleh PT. Mega Utama Development. langkah-langkah yang digunakan untuk pengembangan sistem yaitu; menggunakan tahap-tahap SLDC (System Development Life Cycle). Model yang banyak digunakan dalam pengembangan sistem SDLC adalah waterfall, prototyping, spiral, dan Rapid Application Development (RAD). Model SDLC waterfall (air terjun) sering juga disebut model sekuensial linier atau alur hidup klasik (classic life cycle). Model waterfall (gambar 1) menyediakan pendekatan alur hidup perangkat lunak secara sekuensial atau terurut dimulai dari analisis, desain, pengkodean, pengujian, dan tahap pendukung (support)

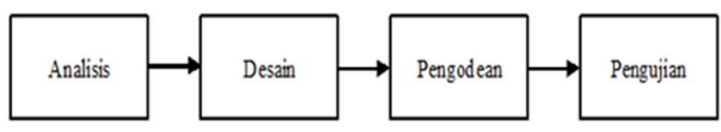

Gambar 1. Model Sistem Waterfall

Pada tahap analisis dilakukan identifikasi masalah pada departmen marketing proyek Apartemen Mega City dengan menggunakan berbagai teknik diantarnya observasi dan wawancara. Pengumpulan data dan informasi yang diperlukan dalam penelitian ini dilakukan dengan melakukan wawancara langsung pada general manejer departement marketing dan tiga orang staf marketing lainnya. Observasi ke lapangan dilakukan dengan mengikuti kegiatan penjualan di divisi marketing PT. 
Mega Utama Development. Dengan dua metode tersebut dapat dikumpulkan data dan informasi, kemudian menganalisa dan mengolahnya untuk kebutuhan pengembangan Sistem Informasi Penjualan Berbasis Kinerja, Kebutuhan penggguna diekstraksi dengan melakukan FGD (Forum Group Discussion). FGD salah satu teknik dalam proses requirement engineering dengan melibatkan pameran kunci [10], hasilnya didokumentasikan dalam bentuk laporan.

Pada tahap perancangan dibuat diagram kontek dan diagram nol untuk memberi gambaran umum sistem yang akan dibuat berdasarkan data pada tahap analisis sebelumnya. Dilanjutkan dengan diagram rinci untuk menggambarkan detail proses di diagram nol. Selanjutnya membuat rancangan basis data untuk masing-masing proses, hubungan aliran data antar proses digambarkan dalam ERD. Perancangan sistem informasi penjualan berbasis kinerja ini dibuat berdasarkan data kebutuhan sistem yang telah diekstraksi sebelumnya.

Tahap pengkodean dilakukan dengan menggunakan Bahasa pemogrraman Java dengan dukungan IDE NetBean dan RDMS MySQL.

Tahap trakhir adalah pengujian dengan menggunakan Teknik black box testing. Menguji fungsi-fungsi pada sistem informasi dengan melakukan satu siklus penjulan

\section{HASIL DAN PEMBAHASAN}

\subsection{Analisa sistem berjalan}

Sistem penjualan unit Apartemen Mega City Bekasi yang berjalan masih sederhana. Proses pencatatan data konsumen yang dilakukan oleh sales eksekutif, proses booking unit apartemen, pencatatan dan penyimpanan data, hingga proses pembuatan laporan masih dilakukan secara manual mengakibatkan sering terjadinya kesalahan dalam pengelolaan data karena human error seperti kesalahan saat mengetik data, menyimpan data dan kesalahan dalam pembuatan laporan. Adapun proses bisnis yang terjadi pada departemen penjualan sebagai berikut:

A. Sales eksekutif akan mencatat data konsumen yang akan membeli unit apartemen.

B. Apabila ada konsumen yang ingin membeli unit apartemen, konsumen menyerahkan dokumen untuk diisikan pada form atau surat pengajuan booking yang disediakan oleh PT. Mega Utama Development.

C. Setelah konsumen mendapatkan surat pengajuan booking, konsumen akan menerima rincian biaya dari sales eksekutif.

D. Setelah konsumen menerima rincian biaya, konsumen akan membayar booking fee pada bagian keuangan (finance) terhadap unit yang sudah dibooking.

E. Data konsumen akan direkapitulasi oleh masing-masing sales eksekutif yang nantinya akan dibuatkan laporan data closing untuk supervisor.

F. Supervisor akan merekapitulasi data closing dari masingmasing sales eksekutif yang dibawahinya, laporan data closing akan diserahkan kepada sales menajer.

G. Data yang dimiliki oleh konsumen merupakan tanggungjawab dari sales eksekutif.

H. Setiap supervisor tidak memiliki hak untuk melihat data konsumen yang diperoleh dari sales eksekutif
I. Setiap sales eksekutif dan supervisor tidak memiliki hak untuk melihat data yang dimiliki oleh sales eksekutif dan supervisor lainnya pada divisi marketing.

J. Hak akses data konsumen hanya dimiliki oleh sales eksekutif dan sales menejer.

K. Hasil data yang telah diolah, akan diarsipkan oleh masing2 karyawan divisi marketing dan disimpan pada komputer berupa olahan data dari aplikasi spreadsheet.

\subsection{Sistem yang diusulkan}

Sistem yang akan diusulkan mengintegrasikan proses bisnis di departemen penjualan dalam sistem terkomputerasisasi. Pembaharuan dari sistem berjalan ke sistem yang diusulkan diharapkan dapat membantu dalam mengatasi permasalahan yang muncul selama ini pada Proyek Apartemen Mega City.

Berdasarkan analisa proses bisnis yang sedang berjalan pada sistem penjualan pada Proyek Apartemen Mega City Bekasi, maka dirancang sistem informasi penjualan baru yang memilki keunggulan dibanding dengan sistem lama. Beberapa keunggulan sistem informasi penjualan proyek berbasis kinerja proyek Apatemen Mega city Bekasi ini adalah:

A. Sistem informasi penjualan menggunakan sistem yang terkomputerisasi dan multi user. Masing-masing user memliki hak akses yang berbeda terhadap fungsi-fungsi di sistem.

B. Proses pengarsipan data konsumen, data booking dan data pembayaran menggunakan database dalam Sistem Informasi penjualan Berbasis Kinerja Pada Proyek Apartemen Mega City Bekasi, dengan demikian keamanan data dapat dijamin.

C. Sistem informasi Penjualan Apartemen ini didukung interface yang interaktif menampilkan lokasi masingmasing unit apartemen perlantai dan status

D. Sistem ini mendukung pencetakan laporan kegiatan untuk penilaian progress penjualan dan kinerja agar dapat terkontrol dengan baik dan mampu mendukung peningkatkan pemasaran pada Proyek Apartemen Mega City Bekasi.

\subsubsection{Diagram Konteks Sistem Diusulkan}

Berdasarkan Analisa kebutuhan sistem informasi penjualan berbasis kinerja dapat digambarkan proses-proses yang dilakukan masing-masing entitas yang terlibat dalam sisteminformasi ini, hubungan antar entitas dapat dilihat di gambar 2 . 


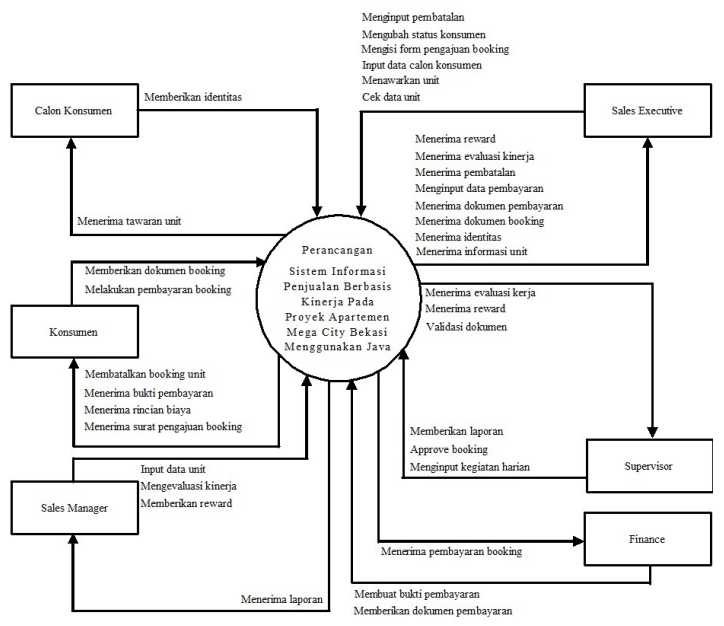

Gambar 2. Diagram Konteks Sistem Diusulkan

\subsubsection{Diagram Nol Sistem Diusulkan}

Berdasarkan Analisa proses bisnis di departemen pemasaran PT. Mega Utama Development terdapat tujuh proses bisnis. Masingmasing proses bisnis diuraikan dalam diagram Nol dapat dilihat pada gambar 3 .

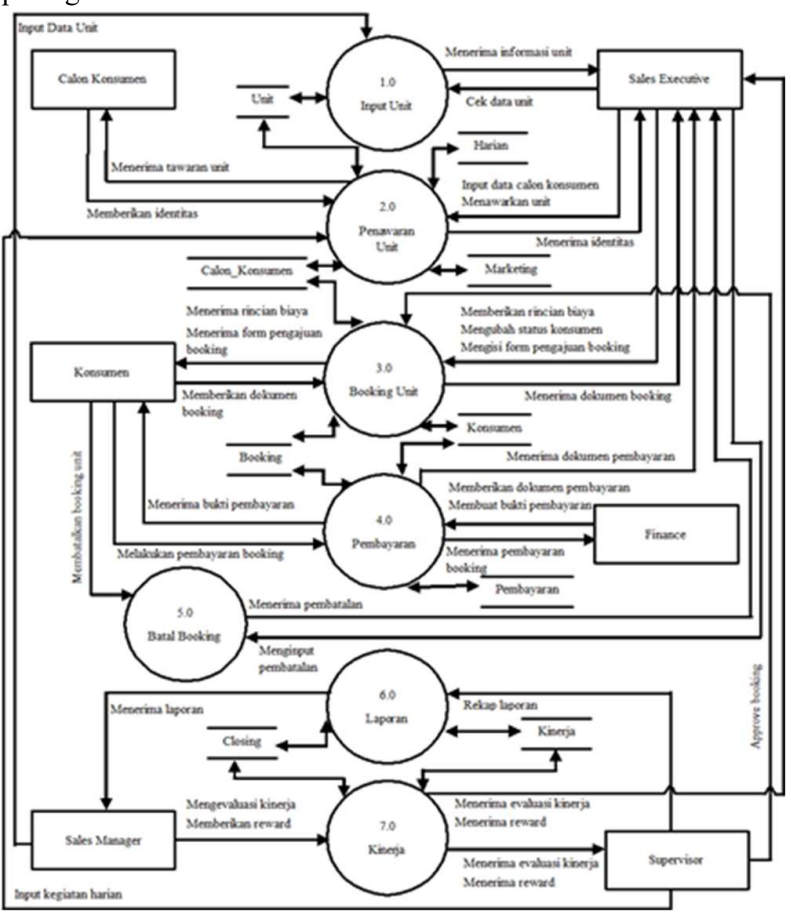

Gambar 3. Diagram Nol Sistem Diusulkan

\subsubsection{Diagram Rinci Sistem Diusulkan}

Untuk mendapatkan gambaran lebih detail pada masing-masing proses pada diagram nol,pProses-proses tersebut selanjutnya diuraikan dalam enam diagram rinci : diagram rinci proses 1.0 input unit ada pada gambar 4, diagram rinci proses 2.0 penawaran unit ada di gambar 5, diagram rinci proses 3.0 Boking unit ada di gambar 6, diagram rinci proses 4.0 pembayaran ada di gambar 7 , diagram rinci proses 5.0 batal booking ada di gambar 8 , diagram rinci proses 6.0 laporan ada di gambar 9 dan diagram rinci proses 7.0 kinerja seperti digambarkan di gambar 10 .

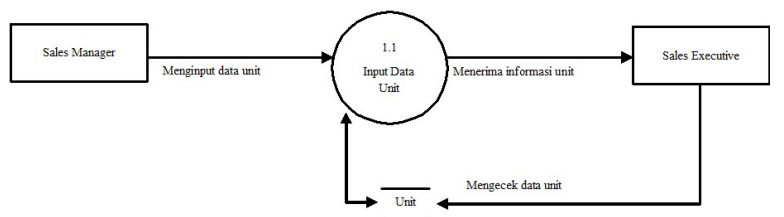

Gambar 4. Diagram rinci proses 1.0 input unit

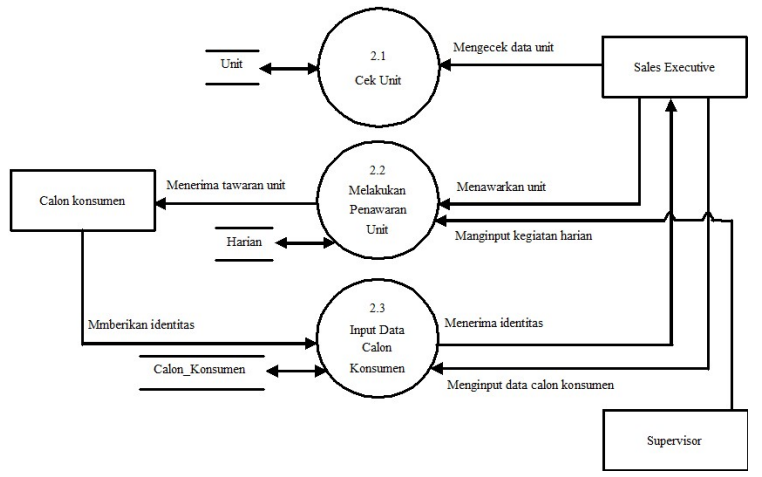

Gambar 5. Diagram rinci proses 2.0 Penawaran unit

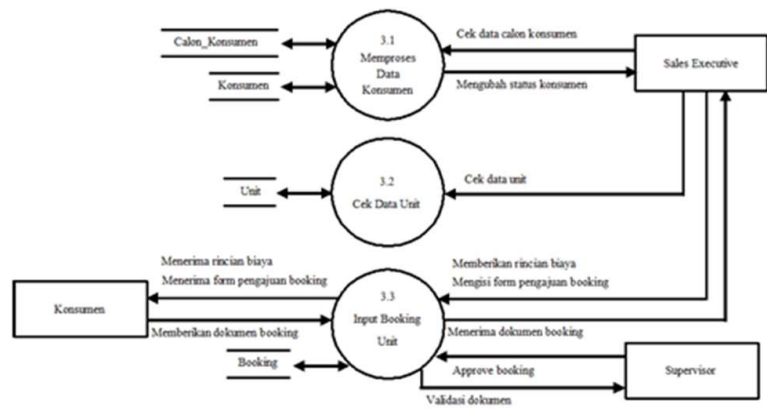

Gambar 6. Diagram Rinci Proses 3.0 Booking unit

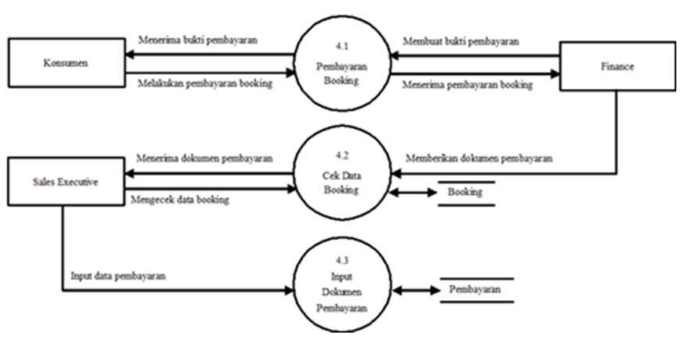

Gambar 7. Diagram Rinci Proses 4.0 Pembayaran

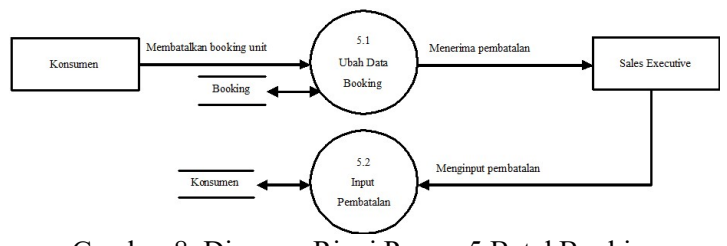

Gambar 8. Diagram Rinci Proses 5 Batal Booking 


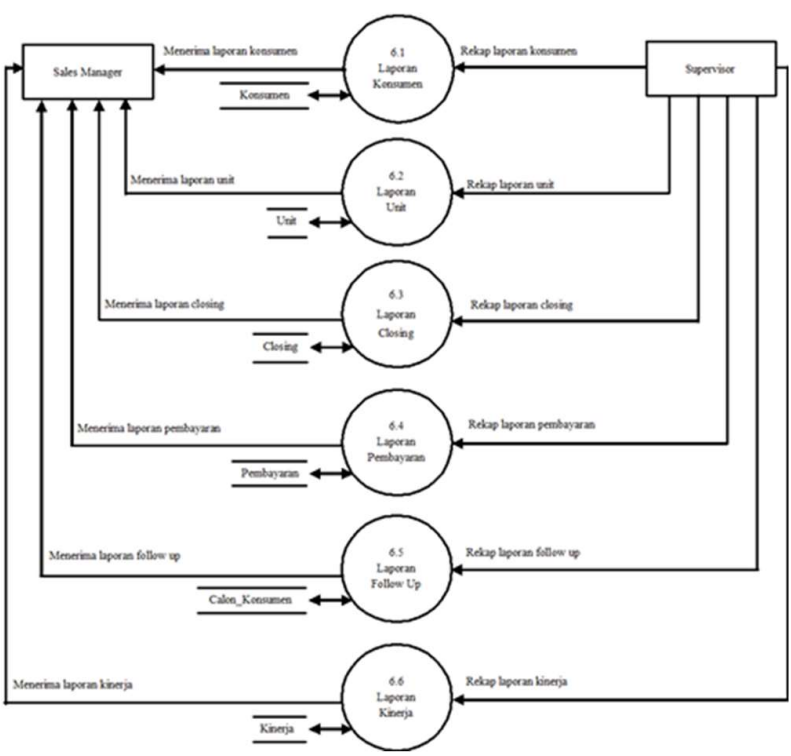

Gambar 9. Diagram Rinci Proses 6 .0 Cetakan Laporan

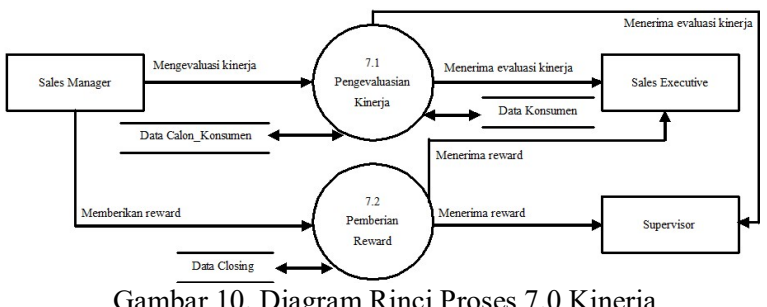

Gambar 10. Diagram Rinci Proses 7.0 Kinerja

\subsection{Perancangan basis data}

Perancangan basis data konseptual ini seperti terlihat di gambar 11 merupakan kelanjutan tahap perancangan dengan model waterfall. Dengan rancangan database ini dapat digambarkan kebututuhan data yang diperlukan untuk membangun sistem baru setelah melakukan analisa kebutuhan data dari dari sistem berjalan pada Proyek Apartemen Mega City Bekasi.

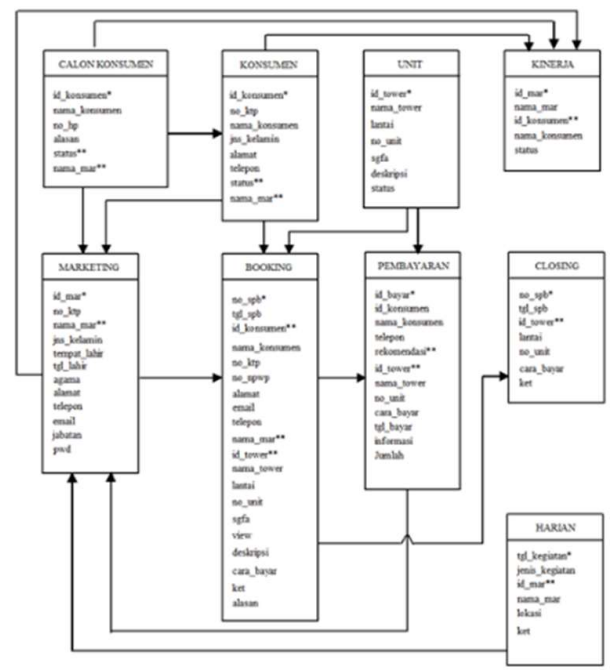

Gambar 11. Rancangan basis data

\subsubsection{Entity Relationship Diagram (ERD)}

Diagram ERD menggambarkan hubungan antar entitas yang masing-masing bersifat unik dan saling berhubungan satu sama lain membentuk sistem informasi penjulan berbasis kinerja ini. Diagram ERD dapat dilihat digambar 12.

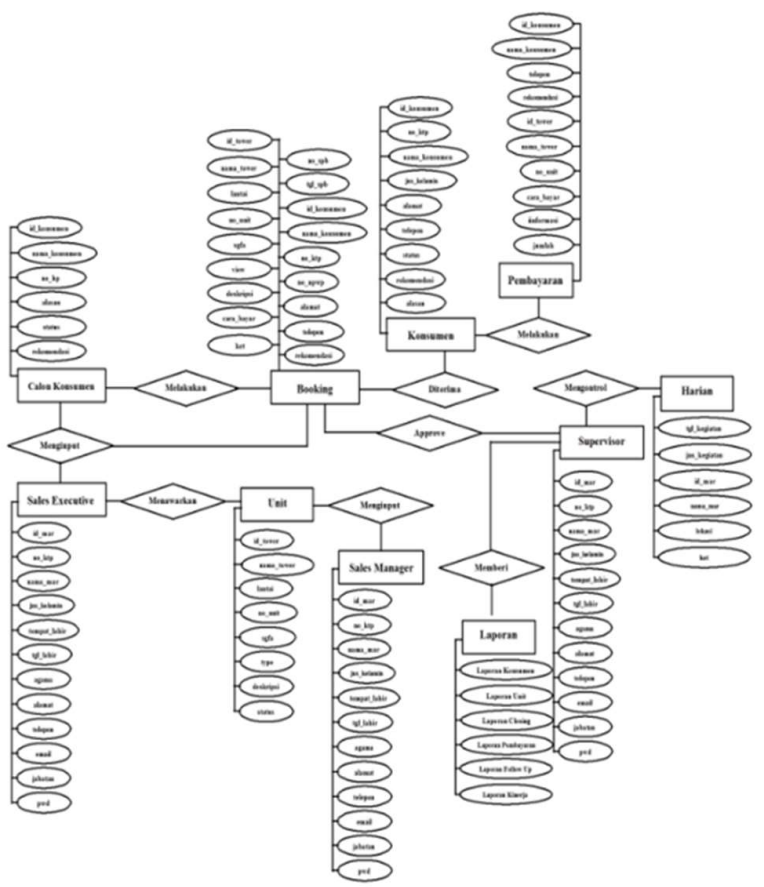

Gambar 12. ERD Sistem informasi penjulan berbasis kinerja

\subsection{Rancangan Interface}

Rancangan interface terdiri dari rancangan input dan rancangan ouput

\subsubsection{Rancangan Masukan (Input)}

Rancangan input masukan terdiri dari rancangan menu utama dapat dilihat pada gambar 13. Menu utama muncul setelah layar login di isi dengan benar. Rancangan input data marketing ada di gambar 13A, input data booking unit ada di gambar 14 . Rancangan form masukan lainnya tidak ditampilkan dalam artikel ini

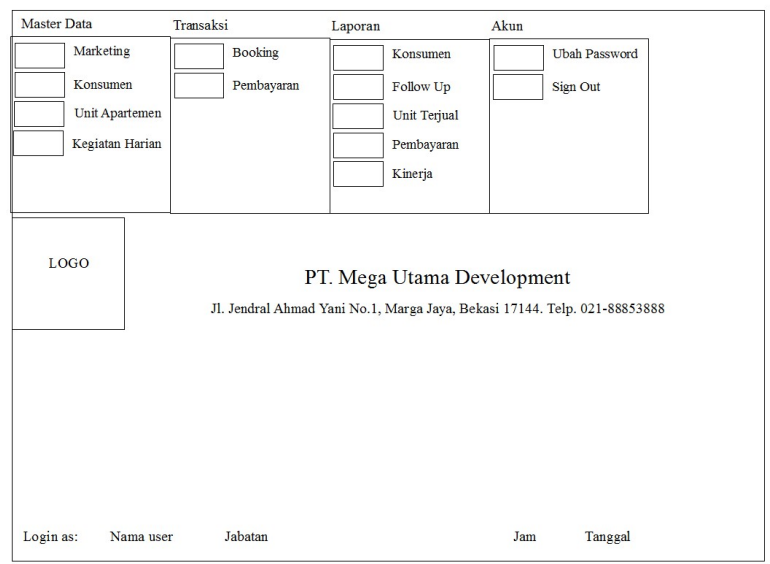

Gambar 13. Rancangan Interface Menu Utama 


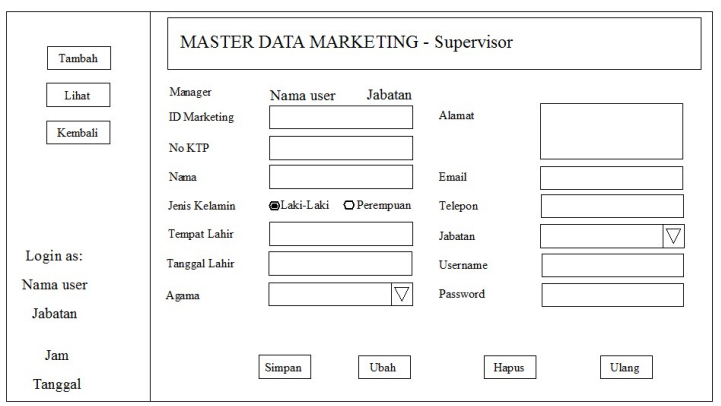

Gambar 13A. Rancangan Interface input data marketing

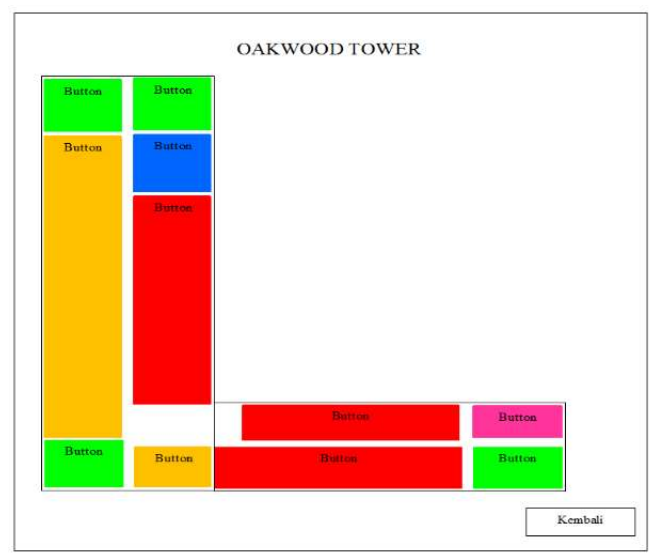

Gambar 14. Rancangan Interface Input Booking Unit

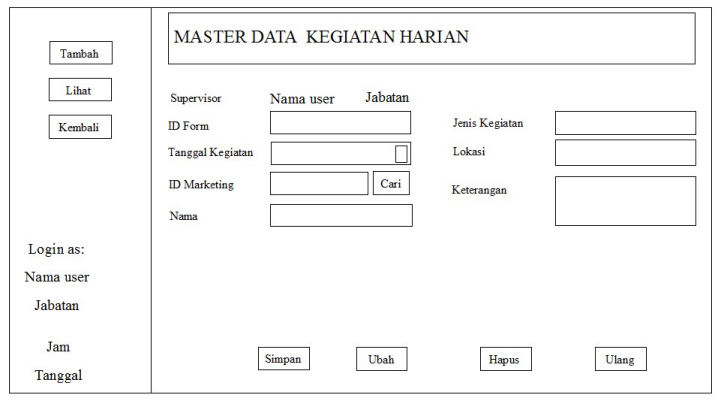

Gambar 15. Rancangan Interface Input Kegiatan Harian

\subsubsection{Rancangan Keluaran (Output)}

Rancangan keluaran terdiri dari enam rancangan, dalam artikel ini hanya ditampilkan dua rancangan laporan, laporan closing seperti pada gambar 16 dan laporan kinerja seperti pada gambar 17.

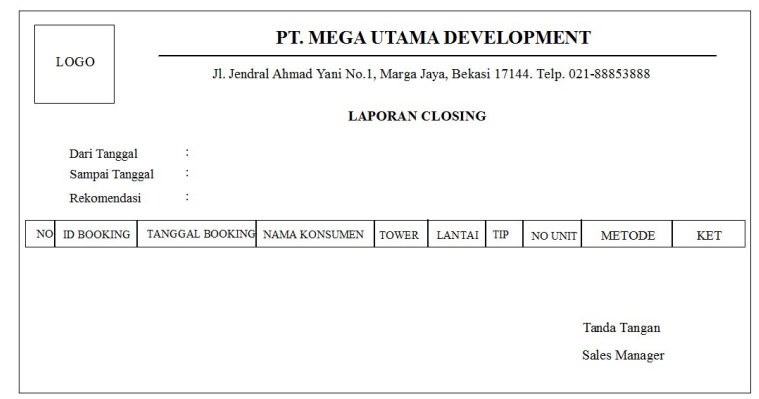

Gambar 16. Rancangan Interface Output Laporan Closing

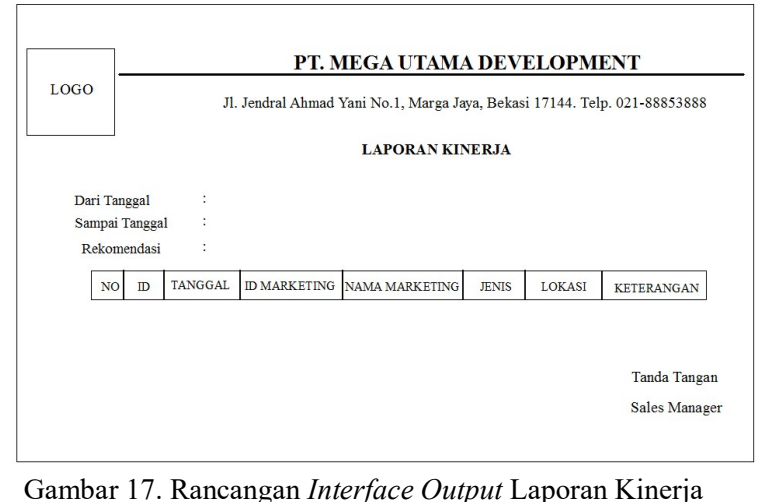

\subsection{Implementasi}

Proses koding dikerjakan berdasarkan rancangan yang telah dibuat. Setelah proses koding, sistem informasi penjulan diimplementasikan. Hasil implementasi sistem dapat dilihat melalui tampilan interface dan form.

\subsubsection{Tampilan masukan (input)}

Pada tampilan input terdiri terdiri dari tampilan interface menu utama dapat dilihat pada gambar 18 , tampilan interface input sales marketing dapat dilihat pada gambar 19, tampilan form kegiatan harian dapat dilihat pada pada gambar 20. Tampilam Form imputan lainnya tidak ditampilkan dalam artikel ini.

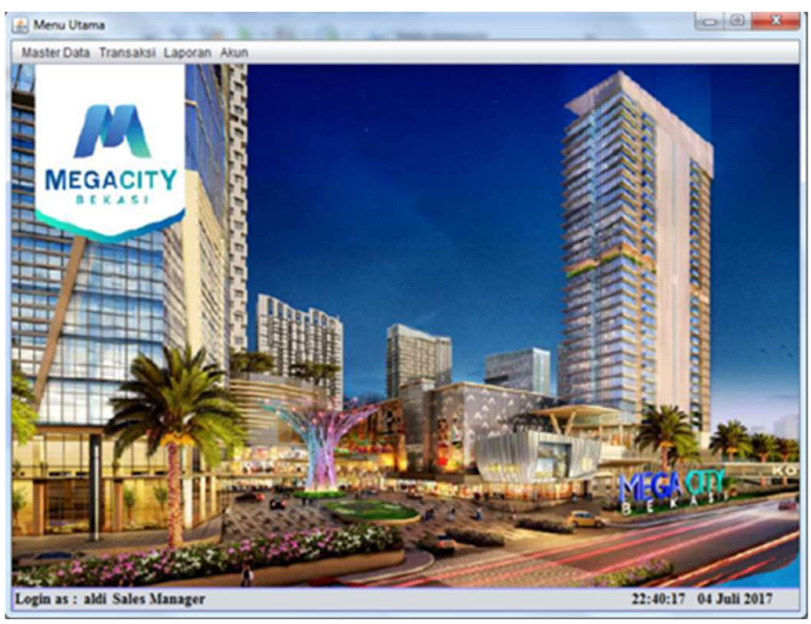

Gambar 18. Tampilan Interface Menu Utama

Pada tampilan menu utama pada gambar 18 terdapat beberapa icon menu yang akan menampilkan form-form masukan, transaksi dan keluaran dalam bentuk laporan. Rincianya sebagai berikut: a). Menu master, menampilkan form-form yang berisikan data marketing, data konsumen, data unit, dan data harian, b). Menu transaksi, menampilkan form-form seperti form booking, dan form pembayaran, c). Menu laporan, menampilkan cetak laporan-laporan yang mengarahkan pengguna (user) pada proses pencetakan laporan-laporan yang dibutuhkan, d). Menu akun, terdiri dari sub menu setting passwaord akun dan sub menu logout untuk keluar dari menu utama 


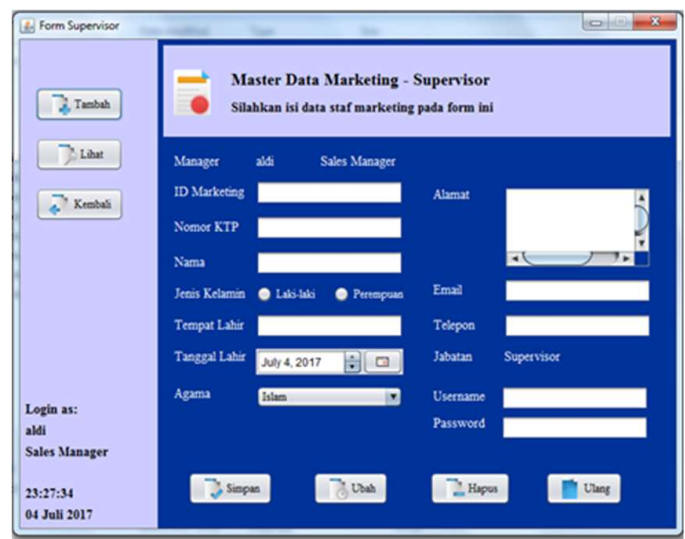

Gambar 19 input data pengguna supervisor (User)

Tampilan form input data pengguna marketing supervisor dapat dilihat padagambar 19, diinput oleh sales manejer. Form ini diisi dengan data-data supervisor diantaranya: ID karyawan, nama karyawan, jenis kelamin, tempat lahir, tanggal lahir, agama, email, alamat, nomor telepon, username dan password awal yang akan diberikan

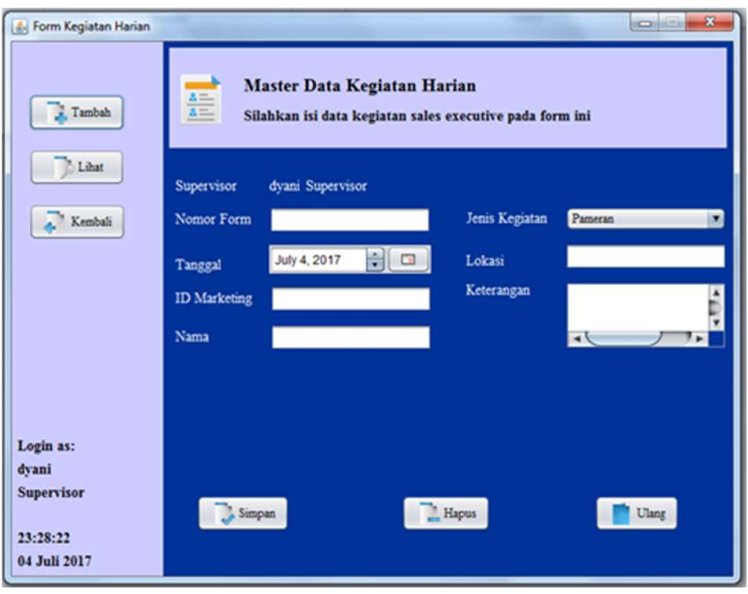

Gambar 20. Tampilan form Input kegiatan harian

Pada form kegiatan harian pada gambar 20 sales eksekutif menginput keiatan-kegitan harian yang dilakukan, sebagai data pendukung untuk menentukan kinerja mereka.

\subsubsection{Tampilan Ttransaksi}

Proses Transaksi terdiri dari dua sub menu yaitu booking dan pembayaran. Pada transaksi booking tersedia empat interface namun hanya tiga interface yang ditampilkan dalam artikel ini: Pertama tampilan halaman fase unit seperti padagambar 21, halaman pilih unit seperti pada gambar 22, dan form pengajuan booking seperti pada gambar 23. Sistem informasi penjualan ini juga menyediakan fungsi pembatalan booking untuk pelanggan yang tidak jadi mengembil unit yang telah dipesan.

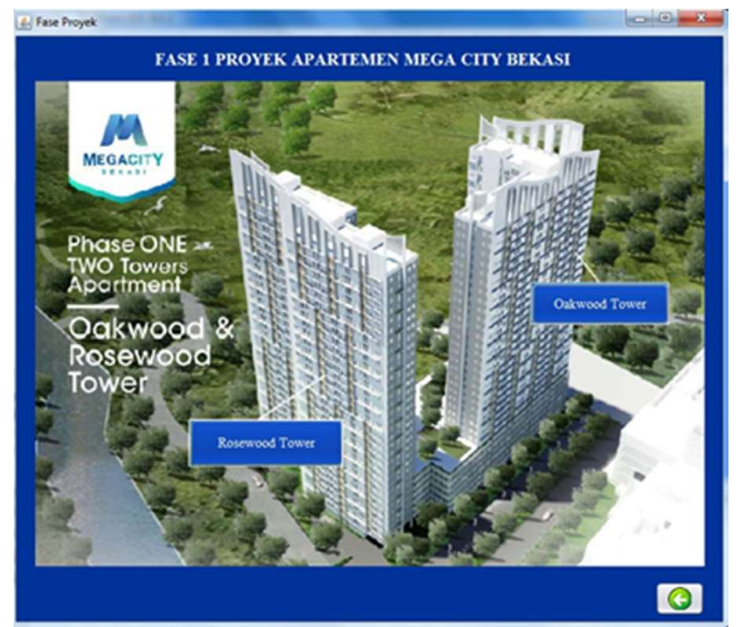

Gambar 21 Tampilan Halaman Fase Unit

Pada tampilan halaman fase unit di gambar 21, kursor bisa diarahkan pada dua tower yang sudah siap jual. Untuk pengecekan status unit yang akan di-booking oleh konsumen sales mengklik salah satu tower yang akan ditawarkan

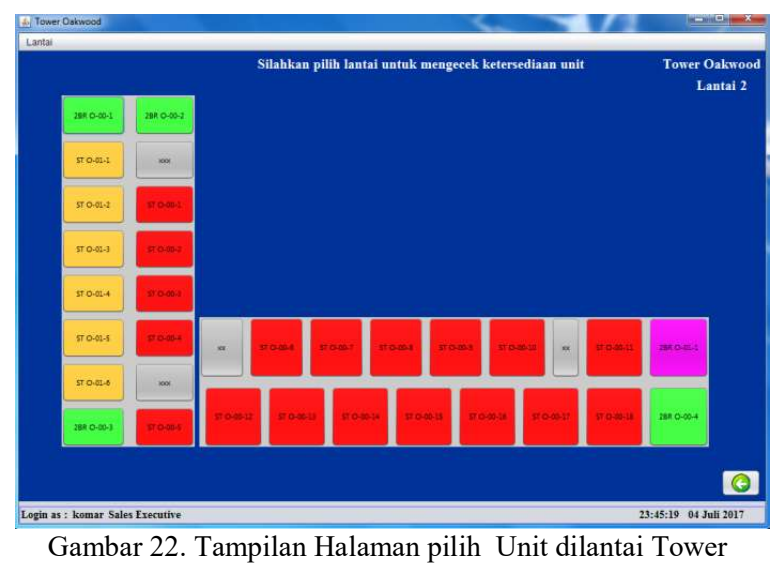

Sebelum masuk ke tampilan halaman layout Oakwood tower lantai 2 seperti terlihat padagambar 22, Marketing terlebih dahulu memilih lantai yang masih menyediakan unit untuk ditawarkan. Pada tampilan lantai tower Oakwood ini terdapat beberapa button dengan warna yang berbeda untuk memberi keterangan pada tipe yang tersedia pada lantai 2 tower tersebut.

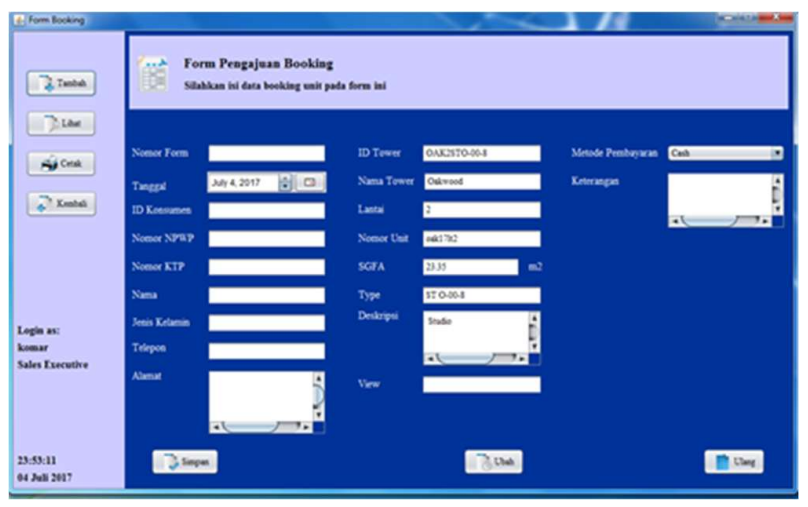

Gambar 23. Tampilan form pengajuan booking

Gambar 23 menampilkan form pengajuan booking muncul setelah marketing meng-klik salah satu button di tampilan sebelumnya (Gambar 22). Form pengajuan booking ini berfungsi 
untuk menginput data booking yang dilakukan oleh konsumen, data yang diinput di antaranya ID booking, tanggal booking, identitas konsumen beserta Nomor Pokok Wajib Pajak (NPWP), data-data unit yang sudah diinput sebelumnya, metode pembayaran yang diambil, dan keterangan booking. Booking juga dapat dibatalkan melalui form pembatalan booking.

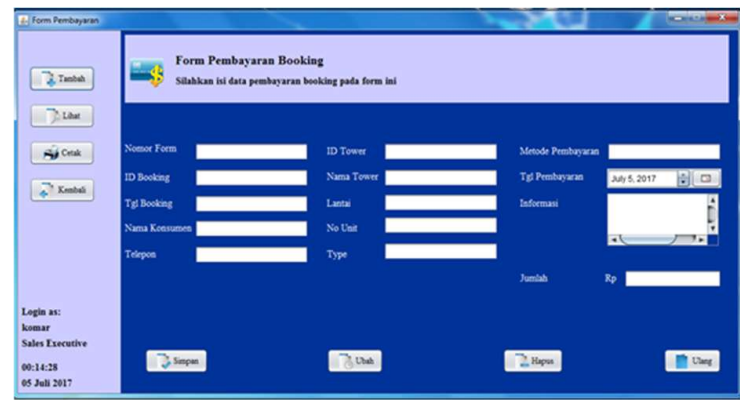

Gambar 24. Tampilan form Input pembayaran

Pada tampilan form transaksi pembayaran seperti pada gambar 24 berfungsi untuk mengarsipkan data pembayaran booking unit apartemen yang dilakukan oleh konsumen, form ini akan diinputkan oleh sales eksekutif. Data yang diinput diantaranya pemanggilan ID booking yang sudah tersimpan dan penginputan data pembayaran yang dilakukan oleh konsumen. Transaksi Selanjutnya seperti pembayaran DP dan pelunasan dilaksanakan di bagian keuangan.

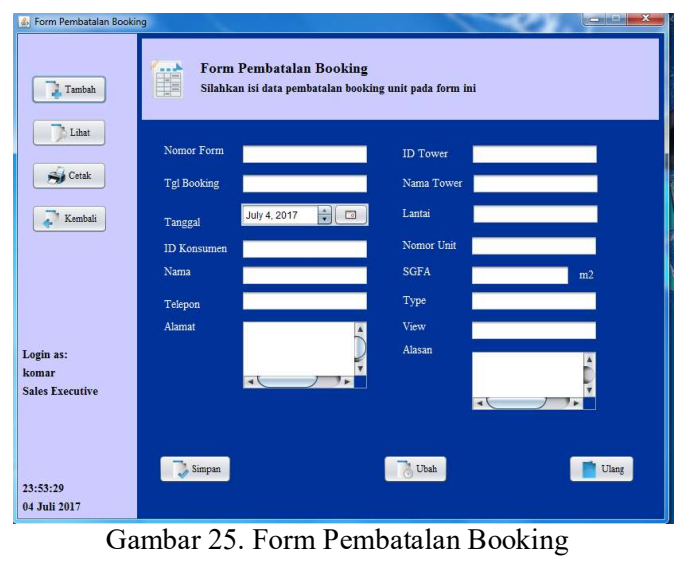

Tampilan form pembatalan booking seperti pada gambar 25 berfungsi untuk menginput data pembatalan booking yang dilakukan oleh konsumen, data yang diinput di antaranya pemanggilan ID form booking yang sudah tersimpan, tanggal pembatalan booking, identitas konsumen, data-data unit yang sudah diinput sebelumnya, dan alasan pembatalan booking.

\subsubsection{Rancangan Keluaran (Output)}

Tampilan output terdiri dari enam laporan, dalam artikel ini hanya ditampilkan hanya bentuk laporan yaitu laporan closing seperti pada gambar 26 dan laporan kinerja seperti pada gambar 27.

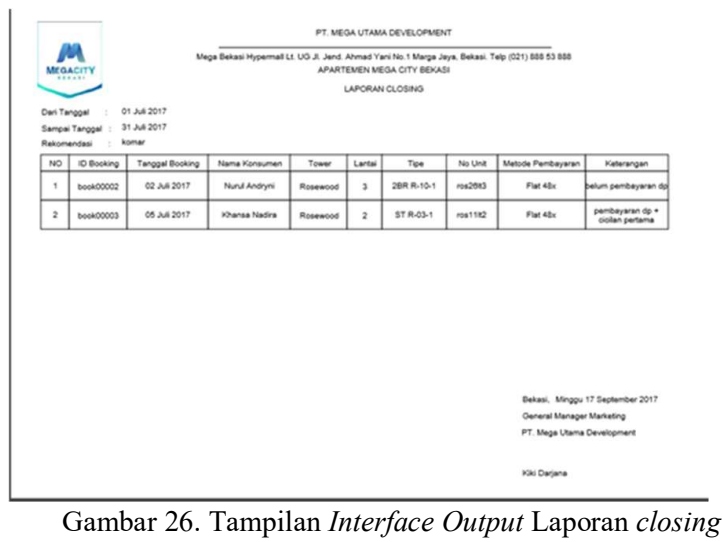

Pengguna (user) dapat mencetak hasil print out dari data-data yang berisi laporan closing (gambar 26) laporan penjualan unit apartemen dapat diperoleh masing-masing tenaga penjual
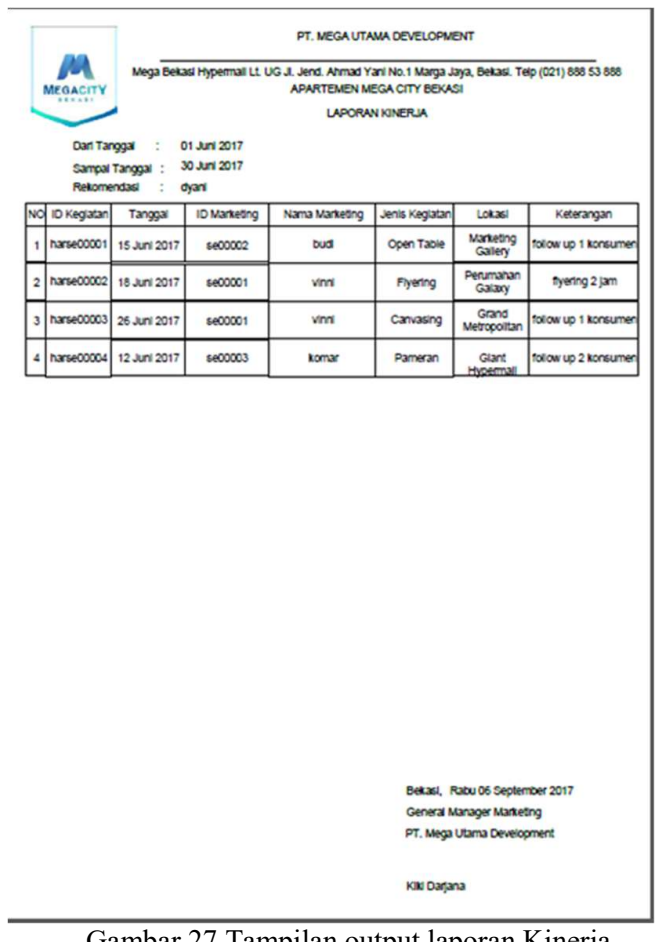

Gambar 27 Tampilan output laporan Kinerja

Pada tampilan laporan, pengguna (supervisor dan sales menejer) dapat mencetak hasil kinerja sales eksekutif (gambar 27) dari data-data yang berisi laporan dari kegiatan harian setiap sales eksekutif yang telah diinputkan oleh masing-masing supervisor pada divisi marketing

\subsection{Pengujian}

Pengujian Black Box sistem informasi penjualan berbasis kinerja pada proyek Apartemen Mega city Bekasi dilakukan dengan menjalankan fungsi-fungsi yang disediakan. Hasil yang diharapkan dibandingkan dengan hasil pengujian. Hasil uji menunjukkan fungsi-fungsi sistem informasi penjualan berbasis kinerja ini mampu menyimpan data dalam database dan menampilkan dalam bentuk view maupun dalam laporan. Untuk laporan kinerja masih dalam bentuk laporan sederhana belum bisa menampilkan kinerja masing-masing tenaga penjulan dalam bentuk visaualisasi dengan tabel. Penentuan kinerja sales

https://doi.org/10.25077/ TEKNOSI.v3i3.2017.343-352 
eksekutif hanya berdasarkan banyaknya interaksi sales eksekutif dengan konsumen berdasarkan laporan calon konsumen yang dihubungi dan berdasarakan banyaknya sales menjual unit apartemen berdasarkan laporan closing. Hasil pengujian dapat dilihat pada tabel 1 .

Tabel 1. Hasil pengujian black box

\begin{tabular}{|c|c|c|}
\hline si & $\begin{array}{c}\text { Hasil yg } \\
\text { diharapkan }\end{array}$ & Hasil uji \\
\hline 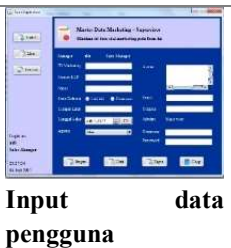 & $\begin{array}{l}\text { Sistem berhasil } \\
\text { menyimpan profil } \\
\text { pengguna. Dan } \\
\text { menampilkan } \\
\text { pesan bila ada } \\
\text { field penting yang } \\
\text { belum di isi }\end{array}$ & $\begin{array}{l}\text { Sistem berhasil } \\
\text { menyimpan data-data } \\
\text { profil pengguna manajer } \\
\text { dan menampilkan pesan } \\
\text { peringatan saat field ID } \\
\text { marketing dan KTP } \\
\text { belum diisi }\end{array}$ \\
\hline $\begin{array}{l}E \\
\text { Kegi }\end{array}$ & $\begin{array}{l}\text { Menyimpan } \\
\text { aktivitas harian } \\
\text { sales eksekutif } \\
\text { sebagai data } \\
\text { masukan untuk } \\
\text { menentukan } \\
\text { kinerja }\end{array}$ & $\begin{array}{l}\text { Data kegiatan harian } \\
\text { masing-masing tenaga } \\
\text { penjul berhasil diinput. } \\
\text { Laporan kinerja } \\
\text { karyawan berdasarakn } \\
\text { data kegiatan harian } \\
\text { berhasil ditampilkan }\end{array}$ \\
\hline Pengajuan Booking & $\begin{array}{l}\text { Sistem berhasil } \\
\text { menyimpan data } \\
\text { pengajuan boking } \\
\text { oleh calon } \\
\text { pelanggan }\end{array}$ & $\begin{array}{l}\text { Sistem berhasil } \\
\text { menyimpan data-data } \\
\text { pengajuan booking oleh } \\
\text { pelanggan }\end{array}$ \\
\hline $\begin{array}{l}=- \\
=-\bar{E} \\
\text { Pembatalan } \\
\text { booking }\end{array}$ & $\begin{array}{l}\text { Sistem berhasil } \\
\text { membatalkan } \\
\text { booking oleh } \\
\text { pelanggan }\end{array}$ & $\begin{array}{l}\text { Data booking berhasil di } \\
\text { cancel. Data unit } \\
\text { kembali dalam status } \\
\text { ready. Dilaporan closing } \\
\text { unit yang dicancel tidak } \\
\text { muncul lagi }\end{array}$ \\
\hline
\end{tabular}

\subsection{Pembahasan}

Sistem informasi Penjualan berbasis Kinerja pada Proyek Apartemen Mega City Bekasi ini dibuat untuk mengintegrasikan proses bisnis di front line dan back end di departemen pemasaran. Aplikasi yang dibangun ini telah sampai pada tahap pengujian fungsi-fungsi oleh pengguna.

Sistem informasi penjulaan berbasis kinerja ini memilki fungsi penentuan kinerja. Fungsi ini tidak ditemukan dalam sistem informasi yang dibangun oleh peneliti lain dalam penelitian sebelumnya, yaitu penelitian [5] dan penelitian [6], dua sistem tersebut hanya membuat sistem untuk kegiatan pemasaran di front line, sedangkan sistem informasi berbasis kinerja ini meliputi kegiatan pemasaran di front line maupun di back end Keuntungan yang diperoleh bila sisteim informasi ini dimplementasikan adalah:

A. Sistem informasi penjualan dapat digunakan untuk kegiatan pemasaran di front line. Bagi sales eksekutif proses interaksi dengan calon komsumen akan lebih interaktif karena pada aplikasi ini ada media gambar interaktif yang dapat menampilkan unit-unit yang tersedia untuk dijual pada masing masing lantai pada tiap tower. Interaksi antara sales eksekutif dan calon pembeli akan lebih ekspresif dengan dukungan fungsi ini.

B. Sistem informasi penjualan ini juga bisa dimanfaatkan untuk proses bisnis penjulana di back end, seperti fungsi

https://doi.org/10.25077/ TEKNOSI.v3i3.2017.343-352 pengukuran kinerja tenaga penjualan yang dapat dimanfaatkan oleh manajer pemasaran untuk mengontrol kegiatan penjualan di bagiannya

C. Fungsi booking pada Sistem infrormasi ini dapat juga dikembangkan dengan mengintegrasikan proses bisnis pembayaran cicilan yang terdapat pada departemen keuangan.

\section{KESIMPULAN DAN SARAN}

Tujuan peneliitan ini adalah untuk membangun sisten informasi penjulan berbasis kinerja memperbaiki cara lama memakai aplikasi spreed sheet. Dengan adanya sistem informasi penjualan ini dapat mengatasi masalah ketidakefektifan dalam siklus penjualan. Setelah sistem informasi ini berhasil dan diuji, dapat disimpulkan siklus kegiatan pemasaran di front line dan di back end dapat terintegrasi dengan demikian proses pemasaran dapat berjalan dengan efektif didukung dengan kemampuan sistem memudahkan pekerjaan di departemen pemasaran diantaranya :

A. Manejer pemasaran dapat mengontrol langsung kinerja para sales eksekutif. Dengan demikian akan memudahkan Menejer pemasaran menentukan reword kepada sales eksekutif yang berkinerja baik dan mengambil tindakantindakan untuk perbaikan bagi sales eksekutif yang berkinerja rendah

B. Proses penjualan unit apartemen menjadi lebih efektif karena data-data pendukung tersedia secara real-time dalam database terintegrasi dan dapat ditemukan secara langsung oleh pengguna, dengan dukungan data terintegrasi ini siklus penjulan menjadi lebih cepat.

Keunggulan sistem informasi ini adalah adanya fungsi penentuan kinerja karyawan yang berjalan di back end. Fungsi ini tidak ditemukan dalam sistem informasi penjulan yang dibangun sebelumnya seperti dalam penelitian [5] dan penelitian [6], Fungsi penentuan kinerja yang masih sederhana dalam aplikasi ini perlu dikembangkan lagi dengan menambahkan dash board dengan dukungan grafik intraktif yang dapat memudahkan manejer pemasaran dalam mengontrol supervisor dan sales eksekutif dibawahnya

Untuk pengembangan lebih lanjut sistem informasi penjualan berbasis kinerja ini bisa ditambahkan fungsi-fungsi diluar departemen penjualan seperti fungsi pembayaran DP dan pembayaan cicilan yang terintegrasi dengan departeman keuangan.

\section{DAFTAR PUSTAKA}

[1] J. Vilaseca-Requena, J. Torrent-Sellens, A. I JiménezZarco, "ICT use in marketing as innovation success factor: Enhancing cooperation in new product development processes", European Journal of Innovation Management, Vol. 10 Issue: 2, 2007,pp.268-288, https://doi.org/10.1108/14601060710745297

[2] A. Michael, E. Jones, A. Rapp, and J. Mathieu (2008), "High Touch through High Tech: The Impact of Salesperson 
Technology Usage on Sales Performance via Mediating Mechanisms," Management Science, 54 (4), 671-685.

[3] A.S.Trihandoko., Sistem Informasi Pemesanan KPR Berbasis Web Pada Perumahan Tamansari Majapahit Semarang, [skripsi] Fakultas Ilmu Komputer Universitas Dian Nuswantoro, 2014, Seamarang

[4] T. Sutabri., Analisis Sistem Informasi. Yogyakarta: ANDI. 2012, pp. 38.

[5] A.R. Riswaya Sistem Penjualan Tunai dan Kredit Property di PT Sanggraha Property, Jurnal Computech dan Bisnis, Vol. 7 No.2 2013

[6] Suryati \& E. P., Bambang Pembangunan Sistem Informasi Pendataan Rakyat Miskin Untuk Program Beras Miskin (Raskin) Pada Desa Mantren

Kecamatan Kebonagung Kabupaten Pacitan, Journal Speed, Vol. 2 No.4, 2010, pp 32-41

[7] R., Tantra., Manajemen Proyek Sistem Informasi: Bagaimana Mengelola Proyek Sistem Informasi Secara Efektif dan Efisien. Yogyakarta: ANDI. 2012, pp. 6.

[8] N. Limakrisna, dan W. H. Susilo, Manajemen Pemasaran: Teori dan Aplikasi Dalam Bisnis. 2012, Mitra Wacana Media, Jakarta

[9] A. S. Ruky. Sistem Manajemen Kinerja (Performance Management System): Panduan Praktis Untuk Merancang dan Meraih Kinerja Prima. 2001, Gramedia Pustaka Utama, Jakarta

[10] K. Falgenti, C., Mai dan S. M. Pahlevi, The design of production modules of ERP systems based on requirements engineering for Electronic Manufacturing Services company, ICITSI 2015, ITB Bandung

\section{BIODATA PENULIS}

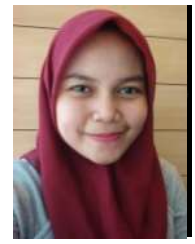

\section{Dyani Ayu Aisyah. S. Kom}

Mahasiswa Universitas Indraprasta PGRI program studi Informatika yang baru saja lulus. Dyani ingin memfokuskan karirnya pada bidang IT dengan konsentrasi database dan Pemograman

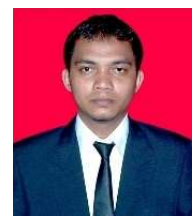

\section{Kursehi Falgenti, M. Kom}

Dosen Teknik Informatika di FTMIPA Universitas Indraprasta PGRI. Anggota IEEE Indonesia Section (2014-2017). Sebelumnya pernah menjadi kolumnis di bidang IT majalah Oase (2014). Kegiatan lain saat ini sebagai reviewer Jurnal Sistem Informasi Indonesia AISINDO dan sebagai System Analyst di www.software-inventory.co.id Perusahaan yang bergerak di bidang pengembangan aplikasi inventory dan aplikasi akuntansi. 